\title{
許容色差に基づくピクセルアート自動生成
}

\section{Method for Automatic Generation of Pixel Art based on Color-difference Tolerance}

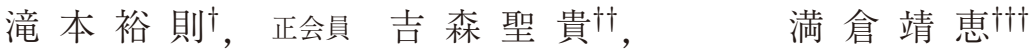

Hironori Takimoto $^{\dagger}$, Seiki Yoshimori ${ }^{\dagger \dagger}$ and Yasue Mitsukura ${ }^{\dagger \dagger}$

\begin{abstract}
In this paper, we propose a technique for automatic generation of pixel art from character images based on color-difference tolerance. Pixel art is one of image expressions for digital images and is based on the pixel level. Character images that are expressed by pixel art are composed of edge lines and a few colors. The proposed technique is for automatically generating pixel art from a photograph where there was only a single object. However, in the conventional method, it is difficult to determine several parameters of edge detection and decrease color for automatic generation of pixel art. In this paper, to create the optimal decreased color image for each target image, we propose a clustering method using a maximum distance algorithm (MDA) based on the human color-difference tolerance. Moreover, the complete automation of making pixel art is achieved by using the result obtained by clustering using the MDA for the threshold decision of the Canny edge detector. As a result, it is shown that several optimum parameters for pixel art are obtained by using the proposed method.
\end{abstract}

キーワード: Image processing, Pixel art, Maximum distance algorithm, Color-difference tolerance

\section{1. ま え がき}

ピクセルアートとは，画素レベルで表現されるデイジタ ル画像表現のひとつであり，その表現手法を用いて制作さ れた画像でもある. 1990 年代半ば以前におけるすべてのコ ンピュータや民生用据え置き型ゲーム等で盛んに用いられ た。計算機や表示デバイスなどのハードウェア性能による 制約によって, ベクトル画像や大規模なビットマップ画像 を使用できなかったため，ゲームのキャラクタや背景など を低解像度の画像表現手法であるピクセルアートを用いて ユーザに提示してきた。 また，ハードウェアの高性能化に より表示可能な画素数や色深度が向上した現在においても， 携帯電話や携帯型ゲーム機などのモバイル端末など，色深 度や画素が限られた状況では主要な表現手法として用いら

2012 年 3 月 14 日受付, 2012 年 5 月 31 日再受付, 2012 年 7 月 2 日採録 $\dagger$ 岡山県立大学 情報工学部

( ₹ 719-1197 岡山県総社市寉木 111, TEL 0866-94-2004)

††日本文理大学 工学部

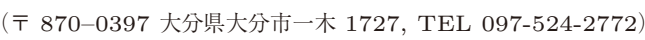
††慶應義塾大学 理工学部

（ \% 223-8522 横浜市港北区日吉 3-14-1, TEL 045-566-1718)

$\dagger$ Faculty of Computer Science and Syst. Eng., Okayama Prefectural University

(111, Kuboki, Soja, Okayama 719-1197, Japan)

$\dagger \dagger$ Faculty of Eng., Nippon Bunri University

(1727, Ichigi, Oita, Oita, 870-0397, Japan)

$\dagger \dagger$ Faculty of Science and Technology, Keio University

(3-14-1 Hiyoshi, Kohoku, Yokohama, Kanagawa 223-8522, Japan)
れている.さらに，高性能なハードウェアを伴う場合でも， GUI におけるアイコンといった重要な役割を担う小さな画 像にピクセルアートを用いる場合もある ${ }^{1)}$.

ピクセルアートの制作には，一般的なグラフィック素材 の制作とは異なる知識が必要とされるため, 熟練したアー ティストによって手作業で制作される。また，制作対象が 低解像度であるため, 作業の綿密さが求められるゆえにピ クセルアートの制作には多大な労力と時間を要する。よっ て，ピクセルアートを半自動的に生成する手法が望まれて いる 2).

画像を簡略化・低解像度化した表現に変換する代表的な 従来法として, Setlur らの手法が挙げられる ${ }^{3)}$. Setlur ら は，オペレーティングシステム用のアイコンを作成するた め，対象となるファイルから内容に沿ったアイコンを自動 的に生成する手法を提案している。しかし，本手法はピク セルアートという表現に特化した手法ではない. 松島らは, シームカービング法を用いたデフォルメした人物に関する ピクセルアートの生成法を提案しているが，あらかじめイ ラスト化された人物画像に特化した手法である ${ }^{4)}$ 。一方, ピクセルアートにはキャラクタ画像と背景画像があり, 一 般的にそれらは異なった表現手法が用いられる。ピクセル アートのキャラク夕画像は，輪郭線と少ない色数で表現さ れていることに着目し，単一オブジェクトのみが写ってい る写真から，自動的にそのキャラクタのピクセルアートを 生成する手法が提案されている ${ }^{2) 5)}$ ，彼らは主に輪郭線の 
抽出とその縮小に注目しており, Maらは, 細線の接続を 考慮した縮小法を提案している ${ }^{5)}$. 一方，鈴木らは，手描 きドット絵 (ピクセルアート) では 8 近傍接続の斜線が多 用されていることを明らかにし, Canny edge detector に 対してドット絵作成に特化した変更を行うことで，より自 然なドット絵風輪郭線を描画している ${ }^{2)}$.

しかし，これらの手法では，輪郭線抽出時のパラメータ の設定が必要であり, 完全な自動化を行えていない. また, キャラクタ画像を少ない色数で表現するため, クラスタリ ング手法を用いて減色画像を生成する必要がある．鈴木ら は，減色画像の生成に k-means 法を用いているが，対象画 像によって適切な色数 (色深度) は異なるため, ピクセル アートの作成対象やその見えによって手動でクラス夕数 $k$ を設定する必要がある。また, 輪郭線検出に関する複数の パラメータも対象画像毎に手動で設定する必要がある。

そこで我々は, キャラクタオブジェクトが写った写真から ピクセルアートを完全自動で生成する手法を提案する。各 対象画像に最適な減色画像を生成するため, 人間の色に関 する許容色差に着目し, 最大距離アルゴリズムに基づくク ラスタリング法を提案する。また, 得られたクラスタリン グの結果を Canny edge detector の閾值決定に用いること で, ピクセルアートのキャラクタ画像作成の完全自動化を 実現する。

\section{2. ピクセルアートと関連研究}

本章では, 専門家によるピクセルアートの作成手順につ いて述べ，ピクセルアート自動生成に関する従来研究とそ の問題点について述べる。なお，専門家がキャラク夕をピ クセルアートとして描く際, 対象の特徵的な部分をデフォ ルメ（誇張・強調）する場合もあるが, 本論文ではデフォ ルメしないピクセルアートを対象とする.

\section{1 人手によるドット絵作成}

ここでは，専門家によるキャラク夕のピクセルアート生成 について述べる，専門家によるピクセルアートの作成手順 は, 準備・輪郭線描画・着色の三つのプロセスからなる ${ }^{6) 7)}$.

手順 1 参照するための高解像度画像 (原画像) を準備する. 手順 2 下絵として, 原画像よりも低解像度の画像を描く. 輪郭線の太さを均一にするとともに, 複数の線が重な り合う個所では，太線にならないよう 1 本にまとめる.

手順 3 領域に着色する.

手順 4 着色した画像に影やハイライトを付加する.

手順 5 下絵を描いた際の輪郭線に着色する。

ただし, 手順 1 と手順 5 は省略される場合もある.

\section{2 半自動化されたドット絵生法}

単一のオブジェクト (キャラクタ) が写っている写真か ら, 半自動でピクセルアートを生成する代表的な手法とし て，鈴木らの手法が挙げられる．論文において鈴木らは，既 存のピクセルアートの輪郭線形状を調査し, 8 近傍接続の
斜線が多用されていることを明らかにした ${ }^{2)}$ •さらに，前 節で述べた専門家によるピクセルアート作成の手順に基づ き, 以下に示す五つの手順から成るピクセルアートの生成 手法を提案した。

手順 1 ノイズ除去として入力画像に非等方性拡散フィル 夕を施す。

手順 $2 \mathrm{k}$-means 法を用いて減色画像を生成する。

手順 3 Canny edge detector を用いて輪郭線画像を生成 する。

手順 4 減色画像に輪郭線画像を重ね合わせる.

手順 5 重ね合わせた画像の輪郭線に着目して縮小する.

鈴木らは, 高階調画像の原画像から低階調の画像を得る ため，等色差空間として知られる CIELAB 色空間 ${ }^{8)}$ 上で k-means 法を用いてクラスタリングすることにより，画像 中の色を量子化（減色化）している。なお，減色化の前処 理として, Peronaらによって提案された非等方性拡散フィ ルタ 9) を複数回施すことによりノイズ除去を行っている.

次に,ノイズ除去後の画像に対して, 8 近傍接続の輪郭線 の抽出に特化した Canny edge detection を用いることで, キャラク夕画像の輪郭線を得ている。その後，得られた輪 郭線画像を減色画像に重ねることで，原画像と同サイズの ピクセルアートが得られる。最後の手順として, 得られた 高解像度のピクセルアートに対して縮小処理を施す. Ma ら の手法で画像の縮小処理を行った場合，不鮮明化や細線が 途切れる，または複数の線が結合して塊になるなどの問題 点があった．鈴木らは，これらの問題を解決するため, 細 線を優先する画像縮小法を提案している。具体的に，段階 的に画像を $1 / 2$ 倍縮小する過程において，上述した細線に 関する問題が発生しないよう，田村の手法 ${ }^{10)}$ を用いて常に 細線化を行っている。

鈴木らの手法は, ピクセルアートの輪郭線に着目し, 細線 化を常に行いながら画像を段階的に縮小することで，8近傍 接続の連続した自然な輪郭線を保つことが可能である。し かし, 非等方拡散の拡散制御量や繰返し回数, Canny edge detectorの二つの閾值など人手によって決定しなければな らないパラメータが複数あり, これらの自動化が課題であ る。また，減色化を行う際のクラスタリング法として非階 層的クラスタリング法である k-means 法を用いているが, クラスタリング結果が初期クラスタの配置に依存し, 不適 切な初期值を選択した場合，間違った解に収束する可能性 がある、さらに, 対象画像によって減色化の際の最適な階 調数が異なると考えられるため, k-means 法のクラス夕数 $k$ を自動で決定する手法が望まれる。一般的に，これらの 問題を解決するため, k-means を改良した k-means $++{ }^{11)}$ やx-means 法 ${ }^{12)}$ が用いられるが，計算コストの問題やど の程度まで階調数を増やすかについて自動で決定すること は困難である。 
表 1 許容色差の分類

Category of color difference tolerance.

\begin{tabular}{c|c|l}
\hline \hline 色差 & 名称 & 摘要 \\
\hline \hline 0.6 & 1 級 & 各種の誤差要因を考えた場合の実用的な許容差の限界 \\
\hline 1.2 & 2 級 & $\begin{array}{l}\text { 並べて判定した場合に, ほとんどの人が容易に色差を } \\
\text { 認めることができる }\end{array}$ \\
\hline 2.5 & 3 級 & $\begin{array}{l}\text { 離間して判定した場合に, ほぼ同一と認めることが } \\
\text { できる }\end{array}$ \\
\hline 5.0 & 4 級 & 経時 比較した場合に, ほぼ同一と認めることができる \\
\hline 10.0 & 5 級 & マーキングペン (JIS S 6037-1992) \\
\hline 20.0 & 6 級 & 色名レベルの色の管理 \\
\hline \hline
\end{tabular}

\section{3. 提 案 手 法}

\section{1 提案手法の概要}

本論文では，キャラクタオブジェクトが撮影された写真か らピクセルアートを自動生成する手法として，鈴木らによっ て提案された手法の各処理（平滑化・減色化·輪郭線検出）に おいて課題であるパラメータの決定について，最大距離アル ゴリズム (Maximum Distance Algorithm: MDA) 13)14) と人間の色知覚における許容色差に基づく手法を提案する. 許容色差とは 2 色の間に色差が認められたときに，それら の色を人間がどのように知覚するかを分類したものであり， 許容色差の分類を表 1 に示す ${ }^{8)}$. なお, 本論文で取り扱う 画像は，単一，もしくは複数のキャラクタオブジェクトが 写ったものであり，その背景には制限を設けない.

\section{2 前処理}

原画像に対して減色化や輪郭線検出を行うための前処理 として，ノイズを除去するために平滑化を施す。我々は， インパルス性雑音も除去可能なエッジ保存平滑化フィルタ であるロバストバイラテラルフィルタ (Robust Bilateral Filter: RBF) ${ }^{15)}$ を平滑化のために用いる.

$n$ 個の画素からなる画像 $f$ が与えられるとし，第 $i \in$ $\{1, \ldots, n\}$ 画素の座標を $x_{i}$, 画素值を $f_{i}$ とすると, $\mathrm{RBF}$ の 出力は

$$
f_{i}^{R}=\frac{\sum_{j \in N_{i}} u_{i j}^{\alpha} \tilde{v}_{i j}^{\beta} w_{j} f_{j}}{\sum_{j \in N_{i}} u_{i j}^{\alpha} \tilde{v}_{i j}^{\beta} w_{j}}
$$

と表される． $N_{i}$ は第 $i$ 画素の近傍画素の集合である．ここ で， $w_{j}$ は各画素 $j$ に対する重みであり,

$$
\begin{aligned}
w_{j} & =\sum_{k \in N_{j}, k \neq j} u_{j k}^{\tilde{\alpha}} v_{j k}^{\tilde{\beta}} \\
& =\sum_{k \in N_{j}} u_{j k}^{\tilde{\alpha}} v_{j k}^{\tilde{\beta}}-1
\end{aligned}
$$

となる。なお， $\tilde{\alpha}$ と $\tilde{\beta}$ は正定数である。また， $u_{i j}$ と $\tilde{v}_{i j}$ は それぞれ空間と画素領域の重みであり，以下のように与え られる。

$$
\begin{gathered}
u_{i j}=\exp \left(-\left\|x_{i}-x_{j}\right\|^{2}\right) \\
\tilde{v_{i j}}=\max \left\{\exp \left(-\left\|f_{i}-f_{j}\right\|^{2}\right), \varepsilon^{\frac{1}{\beta}}\right\}
\end{gathered}
$$

なお， $\varepsilon$ は微小な正定数である。非等方性拡散フィル夕を 用いることで，エッジを保存しつつ，インパルス性ノイズ 等を除去することが可能となる.

\subsection{MDA を用いた減色画像の生成}

エッジ保存した平滑化画像に対して，クラスタリング法 を用いて色空間上で量子化することにより，色深度（諧調 数）を落とした減色画像を生成する。減色化に用いるクラ スタリング法として，我々は，人間の色知覚における許容 色差に基づく MDA を提案する。提案するアルゴリズムを 以下に示す。なお，処理はすべて CIELAB 色空間上で行う こととし，画像 $I$ に属する画素数を $N, i$ 番目の画素が持 つ Lab 色空間上での刺激值を $n_{i}=\left(L_{i}, a_{i}, b_{i}\right)$ とする.

手順 1 Lab 色空間の中心 $(L, a, b)=(50,0,0)$ から最も 離れている画素を初期クラスタ代表点 $Z_{1}$ とする.

手順 2 全ての画素に対して, DIST $T_{i}=\min _{j} d\left(n_{i}, Z_{j}\right)$ を 求め, クラスタラベル $j$ を与える。なお, $d\left(n_{i}, Z_{j}\right)$ は 以下の式で与えられる。

$$
d\left(n_{i}, Z_{j}\right)=\sqrt{\left(L_{i}-L_{j}\right)^{2}+\left(a_{i}-a_{j}\right)^{2}+\left(b_{i}-b_{j}\right)^{2}}
$$

手順 3 各画素のクラスタラベルに基づき，各クラスタ中 心位置をそのクラスタに属する画素の重心位置に更新 する。

手順 4 更新後のクラス夕代表点群について $l=$ $\max D I S T_{i}$ を求める。 $l$ となる画素を新クラス夕代 表点候補 $Z_{N E W}$ とする.

手順 5 もし，lがあらかじめ設定しておいた許容色差の 閾值 Color $_{D I F F}$ よりも大きければ， $Z_{N E W}$ を新たな クラス夕代表点とする。そうでなければ，クラスタリ ング処理を終える。

手順 6 あらかじめ設定しておいた最大クラス夕数 $C_{M A X}$ に達した場合，クラスタリング処理を終える。そうで なければ，手順 2 に戻る。

提案する MDA によるクラスタリング法では，一般的な $\mathrm{MDA}$ とは手順 3 と手順 5 が大きく異なっており，最も離 れた二つのクラスタ代表点間の距離に対する新たなクラス 夕候補とその最近傍となるクラス夕代表点間の距離との比 率ではなく，許容色差に基づいてクラスタリングの終了判 定を行っている.クラスタリングの終了判定に許容色差を 用いることで，従来法で用いられている k-means 法のよう に，画像毎に最適なクラス夕数 $k$ を人手によって求める必 要はなく, x-means 法に比べて高速に各画像に対して同じ 基準で減色化を行うことが可能となる．また，ピクセルアー トが用いられるハードウェアやソフトウェアの制約によっ て，色数が限定される場合が考えられるため，終了条件と して最大クラスタ $C_{M A X}$ 数も追加で設定している. 提案 手法を用いることにより，クラスタリング結果が初期クラ ス夕の配置に依存する従来法の課題を解決可能である. 


\section{4 Canny edge detector による適応的輪郭線検出}

輪郭線については，人間の一般的な領域に対する知覚に 合致した領域分割を行った後，各領域の境界を輪郭線とし て定義（表現）することが望ましい. しかし，ピクセルアー 卜化する対象が未知であり，かつ，ボトムアップ信号のみ を用いる今回のようなケースにおいては，グラフカットに 基づく松尾らの手法 ${ }^{16)}$ などを用いたとしても，過分割が 生じることで結果の見た目に影響を及ぼす可能性がある。

そこで我々は，人が見て顕著に異なる領域（明らかに異 なる色からなる領域）を区別するため, 減色画像に対して 輪郭線を付与することとする。このピクセルアートにおけ る輪郭線に対する基本的な概念は既存手法である鈴木らの 手法と同じである。しかし，前述したように，既存手法で は Canny edge detectorによって輪郭線を抽出する際に用 いられる二つの閾值を画像毎に手動で求めなければならな い。また，高解像度の画像から低解像度の画像まで段階的 に $1 / 2$ 倍縮小を行うことでピクセルアート化を行っている が，細線に関する諸問題を発生させないよう，各段階にお いて細線化を繰返し行っているため, 処理コストの問題が 考えられる.

そこで我々は，人間の色知覚における許容色差に基づい た輪郭線画像生成を行う．提案するアルゴリズムの大まか な流れを示す。

手順 1 原画像の各画素に対して勾配量を計算

手順 2 リサイジング（縮小化）

手順 3 Canny edge detector による輪郭線検出

手順 4 輪郭線以外の画素に対する色の配置

以下，これら処理の詳細について述べる.

まず，カラー画像から輪郭線を抽出するための前処理と して, CIELABにおける画素間の色差の定義式を用いるこ とにより, 任意の点 $(x, y)$ における $x$ 方向の色差 $\left|I_{x}(x, y)\right|$, $y$ 方向の色差 $\left|I_{y}(x, y)\right|$ をそれぞれ次のように定義できる.

$$
\begin{aligned}
\left|I_{x}\right| & =\sqrt{\left(\frac{\partial L *}{\partial x}\right)^{2}+\left(\frac{\partial a *}{\partial x}\right)^{2}+\left(\frac{\partial b *}{\partial x}\right)^{2}} \\
\left|I_{y}\right| & =\sqrt{\left(\frac{\partial L *}{\partial y}\right)^{2}+\left(\frac{\partial a *}{\partial y}\right)^{2}+\left(\frac{\partial b *}{\partial y}\right)^{2}}
\end{aligned}
$$

ここで，画像 I を $\mathrm{x}$ 方向，y方向に微分して生成された画 像をそれぞれ $I_{x}, I_{y}$ とする。

次に, 得られた色差情報からなる画像 $I_{x}, I_{y}$ と減色化後 の画像 $I_{c}$ に対して画像サイズの縮小を行う。目標の縮小倍 率 $r$ を以下のように $(1 / 2)^{n}$ とそれ以外の $1 / t$ に分割する.

$$
r=\left(\frac{1}{2}\right)^{n} \times \frac{1}{t} \quad(1<t<2)
$$

上記の式を $n, t$ それぞれについて解くと,

$$
n=\left\lfloor-\frac{\log r t}{\log 2}\right\rfloor
$$

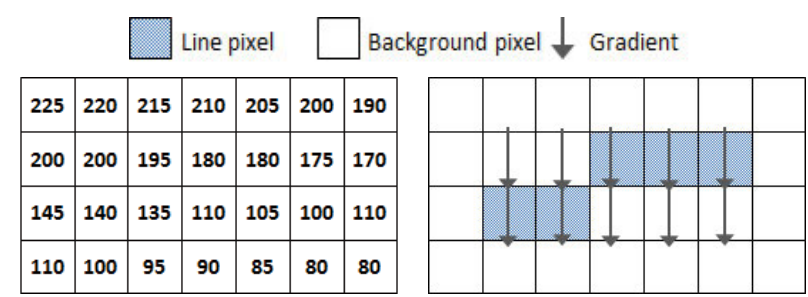

(a) Pixel value (0-255)

(b) Result of edge detection

図 1 格子状の画素に沿った non maximum suppression の例 Examples of non maximum suppression along grid.

$$
t=\left(\frac{1}{2}\right)^{n} \times \frac{1}{r}
$$

となる

まず， $1 / t$ 倍の縮小について $, I_{x}, I_{y}$ に対してバイリニア 補間を用いることで縮小後の画像 $I_{x}^{\prime}, I_{y}^{\prime}$ を得る。一方，減 色化画像 $I_{c}$ については，ニアレストネイバー法を用いるこ とで縮小後の画像 $I_{c}^{\prime}$ を得る. 次に, $I_{x}^{\prime}, I_{y}^{\prime}$ に対して, ダウ ンサンプリング法に基づいて複数画素の平均を求めること で $(1 / 2)^{n}$ 倍の縮小を行う．減色化画像 $I_{c}^{\prime}$ については，前 述したダウンサンプリング処理の対象となった複数画素か らなる領域内において, 最も出現頻度の高い色を保存する ことで縮小化後の画像 $I_{c}^{\prime \prime}$ を得る.

次に, Canny edge detector を用いて, 縮小化された画 像から輪郭線を抽出する。本論文では，鈴木らと同様に，8 近傍接続の斜線を輪郭線として抽出するため, 4 近傍接続 （格子状）に基づく non maximum suppression を行う。ま ず，任意の点 $(x, y)$ における CIELAB を用いた勾配の大 きさ $m(x, y)$ と勾配の方向 $\theta(x, y)$ を以下の式より求める.

$$
\begin{gathered}
m(x, y)=\sqrt{\left|I_{x}(x, y)\right|^{2}+\left|I_{y}(x, y)\right|^{2}} \\
\theta^{\prime}(x, y)=\arctan \frac{I_{y}(x, y)}{I_{x}(x, y)}
\end{gathered}
$$

4 近傍接続に基づく non maximum suppression を行うた め，勾配方向は以下の式によって二值化される.

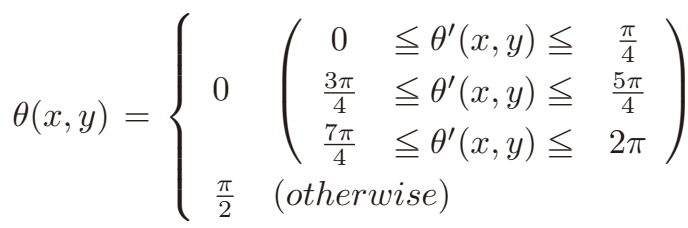

$$
\begin{aligned}
& =\left\{\begin{array}{cc}
0 & \left|I_{x}(x, y)\right| \geqq\left|I_{y}(x, y)\right| \\
\frac{\pi}{2} & \left|I_{x}(x, y)\right|<\left|I_{y}(x, y)\right|
\end{array}\right.
\end{aligned}
$$

このようにして得られた隣接画素との色差を考慮した勾配 の大きさ $m$ と勾配方向 $\theta$ を用いて, Canny edge detector では, 勾配の大きさ $m$ が勾配方向 $\theta$ において極大である画 素を輪郭線画素として出力する。格子状の画素に沿った non maximum suppression の例を図 1 に示す。図 $1(\mathrm{a})$ は $7 \times$ 4 画素を持つ画像の画素值を表しており，図1(b) は図 1(a) に対して格子状の画素に沿ったnon maximum suppression 
を適用した場合の輪郭線画素, 背景画素と勾配方向を表して いる. 勾配方向に沿って non maximum suppression を行 うのではなく，格子状の画素に沿って non maximum suppression を行うことにより，図1(b)のように8近傍接続の 斜線が得られる。しかし，極大のみを条件に輪郭線を抽出 した場合，輪郭線としてふさわしくない局所的なエッジ情 報まで抽出されてしまうため，一般的に，上限と下限の二 つの閾值を用いて，ヒステリシス閯值処理により適応的に 輪郭線の検出を行う。まず，任意の間值 $T_{h}$ と $T_{l}\left(T_{h}>T_{l}\right)$ を設定し, 勾配の大きさ $m$ が勾配方向 $\theta$ において極大で ある画素 $(x, y)$ に扔ける勾配の大きさ $m(x, y)$ について $m(x, y)>T_{h}$ であるならば，輪郭線画素として出力する. 一方, $T_{l}>m(x, y)$ ならば非輪郭線画素とし, それ以外の 場合は, 8 近傍で定義される隣接画素に輪郭線画素が存在 する場合にのみ，画素 $(x, y)$ は輪郭線であるとする.

ここで，従来法に扔いては Canny edge detectorに扔け る二つのパラメータ $T_{h}$ と $T_{l}$ について, 人手によって画像 毎に最適な值を決定していた。この問題を解決するため, 本論文では，原画像の減色化によって得られるクラスタリ ングの結果をこれら䦨值決定に用いる。減色化の結果とし て，Lab 色空間上でクラスタリングされたクラスタ代表点 について, 最も近いクラス夕代表点間の距離を Canny edge detector の上限閾值 $T_{h}$ とする.

$$
T_{h}=\min _{i, j} d\left(Z_{i}, Z_{j}\right)
$$

また，下限の閾值については，Canny edge detectorを用 いてエッジ検出を行っている多くの従来研究 2)17)18) におい て, 経験的に下限間值を上限間值の $1 / 2 \sim 1 / 3$ 倍に設定し ているため, 本論文では経験的に $T_{l}=T_{h} \times(5 / 12)$ として いる。このように，許容色差に基づいてクラスタリングさ れたクラス夕を基準に輪郭線を描画することで，人が見て 顕著に異なる領域を区別するための効果的な輪郭線を表現 することが可能である.

従来法では, Canny edge detector で細線化された輪郭 線を抽出後，田村の細線化 ${ }^{10)}$ を常に行うことで太線にな らないように注意しながら，繰返し画像サイズの縮小処理 を行っている. 提案手法では, 事前に求めた 1 次微分画像 $I_{x}, I_{y}$ に対して縮小処理を施し，目的の大きさまでリサイ ズした後に Canny edge detector を適用することにより， 8 近傍接続の輪郭線を安定して得ることが可能である.

最後に, 輪郭線以外の画素に対して, 縮小化後の減色化 画像 $I_{c}^{\prime \prime}$ を参照し色を配置する。

\section{4. 評 価 実 験}

本章では，提案手法の有効性を検証するため，実画像を 用いた評価実験を行う。まず，改良 MDA を用いた許容色 差に基づく減色化についての評価を行い，適切な色差パラ メー夕を求める. 次に, 提案手法と従来法との比較実験と して，それぞれの手法を用いて生成したピクセルアートに
表 2 減色化画像に対する主観評価結果

The results of subjective evaluation for decrease color.

\begin{tabular}{c||c|c|c}
\hline \hline 許容色差の閾值 & 5.0 & 10.0 & 20.0 \\
\hline \hline 平均 & 3.9 & 3.9 & 2.3 \\
標準偏差 & 0.6 & 0.7 & 0.8
\end{tabular}

対して主観評価実験を行うとともに，得られた輪郭線を定 量的に評価する。

\section{1 許容色差に基づく減色化に関する評価実験}

ここでは，提案手法の減色化過程に扔ける適切な色差パ ラメータを求めるため，主観評価実験を行う。主観評価実 験の方法として，ITU-R で提案されている DSIS 法（The double-stimulus impairment scale method）に基づいた 実験を行う。実験手順として，10 枚の原画像に対し，3 章 にて述べた提案手法の「前処理」と「MDA を用いた減色 化」を適用する．MDA によるクラスタリングの終了判定 に設定する許容色差として，表 1 を参考にし，各原画像に 対して 3 種類 $(5,10,20)$ の許容色差を設定した。次に, 印刷された原画像と減色化後の評価画像それぞれを被験者 に同時に提示し，減色化後の画像が原画像に対してどの程 度劣化したかを 5 段階で評価していただいた。なお，評点 は高いほど良い。実験には、素材辞典フォトバイブルなど から選んだ画像 10 枚を用いた。また，実験に協力頂いた 被験者は，10 代から 30 代までの正常色覚を有する男女 10 名である。前処理としての RBF のパラメー夕は，文献 15) を参考に， $\tilde{\alpha}=0.001, \tilde{\beta}=0.5, \varepsilon=0.64$ とし， $N_{i}$ のサイ ズは $15 \times 15, N_{j}$ のサイズは $7 \times 7$ とした.

主観評価実験の結果として，それぞれの許容色差に対す る評点の平均と標準偏差を表 2 に示す。主観評価の評点は, 高いほど劣化の度合いが低いことを意味している。結果よ り，色差パラメー夕を小さくすることで，より違和感のな い減色化画像を生成可能である。しかし，使用される色数 が増加することにより，ピクセルアートを記憶するのに必 要なメモリーと処理コストの増大などに繋がる。そこで, 許容色差の閾值が 5.0 と 10.0 の場合で結果にほとんど差が ないことから，ピクセルアート化に最適な許容色差の闇值 Color $_{D I F F}=10.0$ とし，以降の実験を行う.

\section{2 輪郭付与とリサイジング}

提案手法の有効性を検証するため，従来法の中でも代表 的な手法である鈴木ら 2) の手法を用いて比較実験を行う。

まず，提案手法と既存手法それぞれを用いて得られる輪 郭線について定量的な評価を行うため, 得られた輪郭線画 像から輪郭線を構成する様々な部分形状の出現回数を調べ た. 本論文では，輪郭線の部分形状の分類について，文献 2) に基づいて図 2 のように定義した。この図は，輪郭線上の 各画素を中心とする $2 \times 3$ 画素を示しており，回転や反転 で同形状となるものは同一のものとして扱っている。なお， 輪郭線形状によっては，同時に複数分類されることがある ことに注意する，非細線に分類される形状として，中央画 


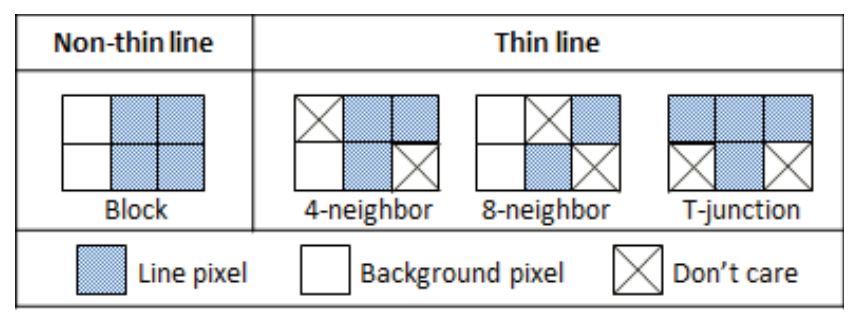

図 2 細線と非細線

Thin lines and a non-thin line.

素とその右上，上，右画素が輪郭線画素である形状を「塊 (Block)」と定義した，一方，それ以外の細線に分類される 形状として, 文献 2) では 5 種類定義しているが, 本論文で は，ピクセルアートの輪郭線を評価するに適していると考 えられる「4 近傍接続の斜線 (4-neighbor)」と「8 近傍接続 の斜線 (8-neighbor)」,「T 字 (T-junction)」を定義した.

実験結果として, 図 3(a) の画像に対して提案手法と従来 手法を適用した場合の結果を表 3 に示す，提案手法では，許 容色差の閾值 $C_{\text {O }}$ olor $_{D I F F}=10.0$ とし， 3 章にて述べた手 順に従って得られた輪郭抽出のための闇值を用いた。一方, 従来手法に対して, 提案手法によって得られた閾值と同じ 值を適用した。なお，それぞれの手法で生成された輪郭線 のみの画像として, 提案手法の結果を図 $3(\mathrm{~b}) \sim(\mathrm{g})$ に, 従来 法の結果を図 $3(\mathrm{~h}) \sim(\mathrm{m})$ にそれぞれ示す。結果より，提案 手法で検出した輪郭線には，どの縮小率においても Block が含まれていない。一方，従来手法では，縮小率が小さく なるにつれ，輪郭画素数に対する 8-neighbor 以外の発生割 合が高くなっている。アーティストによって制作されたピ クセルアートの輪郭線には，8近傍接続の斜線が多用され ていることから, 提案手法が従来法よりもより自然なピク セルアートを生成できていることがわかる。

しかし，画像サイズを縮小する前に輪郭線検出をしてい る従来手法に比べ, 縮小後に輪郭線を検出する提案手法で は, 得られる輪郭線を構成する画素数が少ないことがわか る。この影響により, 図 3(f) からも明らかなように, 輪郭 線が一部途切れる場合があることが確認できた。しかし，主 要な輪郭線は検出できており, 得られた輪郭線はもとのオ ブジェクトの形状を充分表現できている.

次に，提案手法と既存手法それぞれを用いて生成される ピクセルアート画像について, 主観評価実験を行った。提 案手法では, 許容色差の䦭値 Color $_{D I F F}=10.0$ とし, 3 章にて述べた手順に従ってピクセルアートを自動生成した。 輪郭線抽出のための閾值パラメータは，MDAによるクラ スタリングの結果に基づいて自動で決定される。なお，減 色化に㧍ける MDA の終了条件である最大色数は 24 色（輪 郭線の色を含む）としている.

一方，従来手法である鈴木らの手法では，非等方性拡散 の拡散を制御するパラメータ $K$ と，その繰り返し回数 $i$ に ついては, 各画像に対して最適になるように調整した。減 色化における色数は, 文献を参考に輪郭線の色（黒）を含

表 3 輪郭線画像を構成する部分形状の出現頻度

The frequency of edge parts.

\begin{tabular}{c|c||c|c|c}
\hline \hline & 縮小率 & 1.0 & $0.75\left(\frac{1}{1.33}\right)$ & $0.5\left(\frac{1}{2}\right)$ \\
& サイズ & $500 \times 375$ & $375 \times 281$ & $250 \times 186$ \\
\hline \hline 提 & 輪郭画素数 & 8198 & 5482 & 2813 \\
案 & Block & 0 & 0 & 0 \\
手 & 8-neighbor & 3479 & 2471 & 1205 \\
法 & 4-neighbor & 141 & 125 & 46 \\
& T-junction & 31 & 31 & 17 \\
\hline 従 & 輪郭画素数 & 7520 & 4854 & 3352 \\
来 & Block & 0 & 0 & 10 \\
手 & 8-neighbor & 3487 & 2398 & 1027 \\
法 & 4-neighbor & 70 & 89 & 665 \\
& T-junction & 22 & 25 & 319 \\
\hline \hline & 縮小率 & $0.3\left(\frac{1}{2} \times \frac{1}{1.67}\right)$ & $0.1\left(\frac{1}{2^{3}} \times \frac{1}{1.25}\right)$ & $0.05\left(\frac{1}{2} \times \frac{1}{1.25}\right)$ \\
& サイズ & $150 \times 112$ & $50 \times 37$ & $25 \times 19$ \\
\hline 提 & 輪郭画素数 & 1257 & 197 & 60 \\
案 & Block & 0 & 0 & 0 \\
手 & 8-neighbor & 498 & 96 & 19 \\
法 & 4-neighbor & 20 & 3 & 1 \\
& T-junction & 6 & 1 & 0 \\
\hline 従 & 輪郭画素数 & 1544 & 249 & 0 \\
来 & Block & 7 & 1 & 25 \\
手 & 8-neighbor & 509 & 76 & 15 \\
法 & 4-neighbor & 277 & 45 & \\
& T-junction & 145 & 24 & 0 \\
\hline & & & & 0 \\
\hline
\end{tabular}

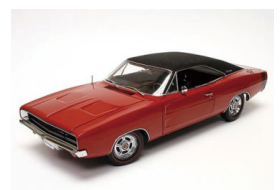

(a) 原画像

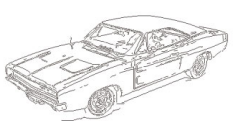

(b) 提案手法 (1.0)

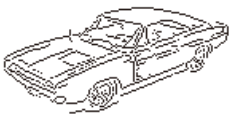

(e) 提案手法 (0.3)

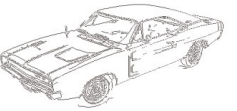

(h) 従来手法 (1.0)

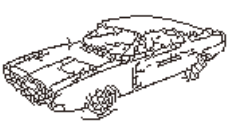

(k) 従来手法 (0.3)

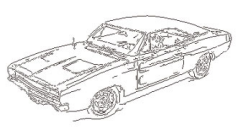

(c) 提案手法 (0.75)

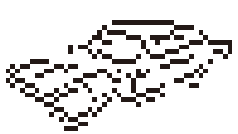

(f) 提案手法 (0.1)

(g) 提案手法 (0.05)
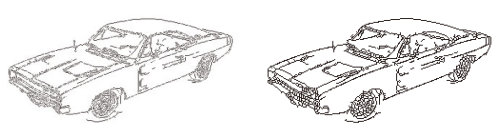

(i) 従来手法 (0.75)

(j) 従来手法 (0.5)

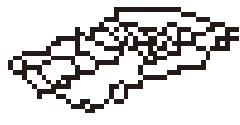

(1) 従来手法 $(0.1)$

(m) 従来手法 (0.05) 図 3 提案手法と従来法による輪郭線の抽出結果 (拡大率) The result of edge line extraction by ours and conventional method.

\section{む 16 色とした。}

また，拡大縮小については，複数の縮小率 $(0.75$ 倍, 0.5 倍, 0.3 倍, 0.1 倍, 0.05 倍）を適用した。実験に用いた画 像は, 前節の実験で用いた画像と異なる 10 枚を素材辞典 フォトバイブルなどから用意した。実験に用いた画像を図 


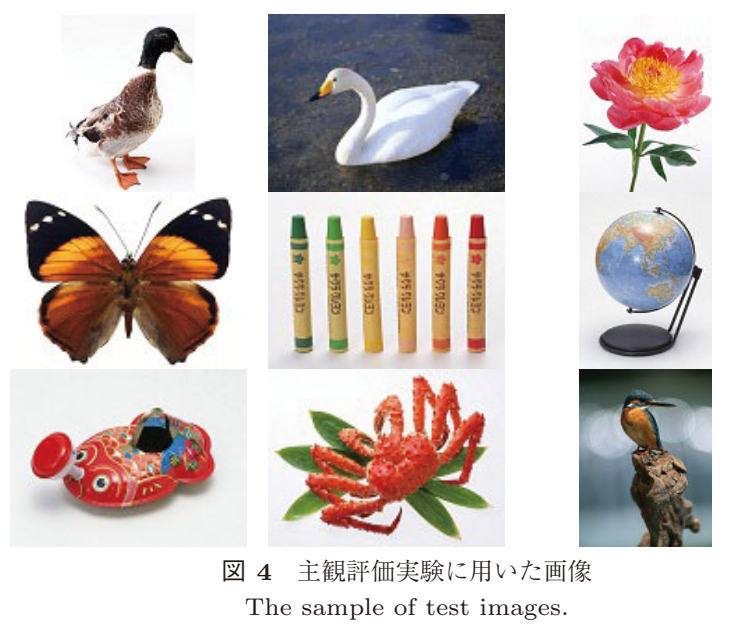

表 4 生成されたピクセルアートに対する詳細な主観評価結果 The detail results of subjective evaluation for each created pixel art.

\begin{tabular}{c||c|c|c}
\hline \hline No. & 提案法 & 従来法 & 従来法 \\
& & $T_{h}=30$ & $T_{h}=10$ \\
\hline \hline 1 & 3.2 & 3.4 & $\mathbf{4 . 2}$ \\
2 & $\mathbf{4 . 1}$ & 3.4 & 3.3 \\
3 & $\mathbf{3 . 7}$ & 3.1 & 2.1 \\
4 & 3.2 & 3.0 & $\mathbf{3 . 4}$ \\
5 & 4.1 & 3.9 & $\mathbf{4 . 2}$ \\
6 & 2.9 & 2.8 & $\mathbf{3 . 1}$ \\
7 & 3.6 & $\mathbf{3 . 7}$ & 2.5 \\
8 & $\mathbf{4 . 0}$ & 3.0 & 3.8 \\
9 & 3.0 & 2.8 & $\mathbf{3 . 1}$ \\
10 & $\mathbf{3 . 7}$ & 3.3 & 3.6 \\
11 & 3.2 & 2.9 & $\mathbf{3 . 6}$ \\
12 & $\mathbf{3 . 7}$ & 2.6 & 2.7 \\
13 & 3.9 & 3.7 & $\mathbf{4 . 3}$ \\
14 & $\mathbf{3 . 6}$ & 2.5 & $\mathbf{3 . 6}$ \\
15 & 4.4 & 3.8 & $\mathbf{4 . 8}$ \\
16 & $\mathbf{4 . 1}$ & 3.5 & 3.3 \\
17 & $\mathbf{4 . 1}$ & 2.7 & 3.6 \\
18 & $\mathbf{3 . 6}$ & 3.1 & $\mathbf{3 . 6}$ \\
19 & $\mathbf{3 . 9}$ & 3.3 & 2.0 \\
20 & $\mathbf{3 . 2}$ & 2.7 & 3.0 \\
21 & $\mathbf{2 . 9}$ & 2.5 & 2.8 \\
22 & $\mathbf{3 . 0}$ & 2.0 & 2.8 \\
23 & $\mathbf{3 . 2}$ & 1.9 & 2.3 \\
24 & $\mathbf{3 . 3}$ & 1.8 & 3.2 \\
25 & 3.1 & 1.7 & $\mathbf{3 . 3}$ \\
\hline \hline
\end{tabular}

\begin{tabular}{c||c|c|c}
\hline \hline No. & 提案法 & 従来法 & 従来法 \\
& & $T_{h}=30$ & $T_{h}=10$ \\
\hline \hline 26 & $\mathbf{2 . 5}$ & 1.3 & 2.3 \\
27 & $\mathbf{3 . 1}$ & 1.7 & $\mathbf{3 . 1}$ \\
28 & $\mathbf{2 . 9}$ & 1.7 & 2.6 \\
29 & $\mathbf{3 . 2}$ & 2.0 & $\mathbf{3 . 2}$ \\
30 & $\mathbf{3 . 4}$ & 2.5 & 3.1 \\
31 & $\mathbf{3 . 0}$ & 2.2 & 1.4 \\
32 & $\mathbf{3 . 0}$ & 2.1 & 1.5 \\
33 & $\mathbf{2 . 7}$ & 2.4 & 2.6 \\
34 & $\mathbf{2 . 9}$ & $\mathbf{2 . 9}$ & 2.4 \\
35 & $\mathbf{3 . 4}$ & 2.2 & 2.8 \\
36 & $\mathbf{3 . 0}$ & 2.6 & 2.3 \\
37 & $\mathbf{3 . 2}$ & 2.5 & 2.5 \\
38 & $\mathbf{3 . 0}$ & 2.5 & 2.3 \\
39 & 2.4 & 2.2 & $\mathbf{2 . 5}$ \\
40 & 1.9 & $\mathbf{2 . 8}$ & 1.2 \\
41 & $\mathbf{2 . 3}$ & 1.6 & 1.9 \\
42 & $\mathbf{1 . 9}$ & 1.1 & 1.1 \\
43 & $\mathbf{2 . 6}$ & 2.1 & 1.7 \\
44 & $\mathbf{2 . 0}$ & 1.6 & 1.6 \\
45 & $\mathbf{2 . 6}$ & 2.1 & 1.6 \\
46 & $\mathbf{2 . 6}$ & 2.5 & 1.5 \\
47 & $\mathbf{2 . 8}$ & 2.0 & 1.8 \\
48 & $\mathbf{2 . 3}$ & 1.7 & 1.5 \\
49 & 1.3 & 1.4 & $\mathbf{1 . 5}$ \\
50 & $\mathbf{2 . 8}$ & 2.4 & 1.9 \\
\hline \hline & & & \\
\hline
\end{tabular}

3(a) と図 4 に示す。なお，実験に協力頂いた被験者は，10 代から 30 代までの正常色覚を有する前節の実験とは異な る男女 15 名である。主観評価実験の方法として，前節と 同様にDSIS 法に基づいた実験を行った。実験手順として, 原画像に対し，提案手法と既存手法（二組の異なる闇值） を適用して 3 枚のピクセルアート画像を得る。なお，従 来法での輪郭線抽出のための閾值パラメー夕には二組の值 $\left(T_{h}=\{15,30\}, T_{l}=T_{h} / 3\right)$ を適用した。次に, 印刷され た原画像と得られた処理後の評価画像 3 枚それぞれを被験 者に同時に提示し，原画像に対するピクセルアートとして の完成度を 5 段階で評価していただいた。

結果として，表 4 にそれぞれの手法を用いた場合の各実 験画像（画像 10 枚 $\times 5$ 種類の縮小率）に対する主観評価 結果を示す。ここでは, 被験者 15 名による評点の平均を示
表 5 生成されたピクセルアートに対する主観評価結果

The results of subjective evaluation for created pixel arts.

\begin{tabular}{c|c||c|c|c|c|c}
\hline \hline & $\begin{array}{c}\text { 拡大率 } \\
(\text { No. })\end{array}$ & $\begin{array}{c}0.75 \\
(1 \sim 10)\end{array}$ & $\begin{array}{c}0.5 \\
(11 \sim 20)\end{array}$ & $\begin{array}{c}0.3 \\
(21 \sim 30)\end{array}$ & $\begin{array}{c}0.1 \\
(31 \sim 40)\end{array}$ & $\begin{array}{c}0.05 \\
(41 \sim 50)\end{array}$ \\
\hline \hline 提案法 & 平均 & $\mathbf{3 . 7}$ & $\mathbf{3 . 5}$ & $\mathbf{3 . 2}$ & $\mathbf{2 . 8}$ & $\mathbf{2 . 2}$ \\
$T_{H}$ は可変 & 標準偏差 & 0.5 & 0.4 & 0.2 & 0.2 & 0.4 \\
\hline 従来法 & 平均 & 3.2 & 3.0 & 2.1 & 2.3 & 1.9 \\
$T_{H}=30$ & 標準偏差 & 0.4 & 0.6 & 0.4 & 0.4 & 0.5 \\
\hline 従来法 & 平均 & $\mathbf{3 . 7}$ & 3.0 & 2.8 & 2.2 & 1.5 \\
$T_{H}=10$ & 標準偏差 & 0.5 & 0.7 & 0.3 & 0.5 & 0.3 \\
\hline \hline
\end{tabular}

しており，主観評価の評点は高いほど良い結果であること を意味している。また，図 $3(\mathrm{a})$ と図 4 で示した 10 枚の評 価画像に対して, No. 1〜10 は拡大率 0.75 , No. 11 20 は拡大率 0.5 , No. 21〜30 は拡大率 $0.3 ，$ No. 31〜 40 は 拡大率 0.1 , No. 41〜 50 は拡大率 0.05 の結果をそれぞれ 意味している。結果より，多くの場合に扔いて，提案手法 の評点が従来手法と比べて同等以上の結果を得ている。 ま た，各縮小率に対する評点の平均と標準偏差を表 5 に示す. 結果より，提案手法は従来手法に比べて高い評点を得てお り，かつ，対象画像毎に評価のばらつきが小さいことがわ かる。な扔，提案手法を用いて生成されたピクセルアート について，ピクセルアートを構成する減色化後の色数は平 均で 16.8 色（輪郭線の色を含む），標準偏差 5.1（最少 7 色，最大 24 色）であった。これらょり，人間の色に関する 許容色差に着目することで，ピクセルアート化する際の処 理対象画像に最適な各種パラメー夕を自動で決定可能であ ることを確認できた。最後に，提案手法による描画例を図 5 に示す，それぞれの左端の画像が入力写真である。右側は 入力に対する提案手法を用いたピクセルアートであり, 縮 小率はそれぞれ 100\%，70\%，40\%，20\%，10\%である.

\section{5.むすび}

本論文では，キャラクタオブジェクトが写った写真から ピクセルアートのキャラクタ画像を完全自動で生成するた め, 人間の色に関する許容色差に着目した手法を提案した. 許容色差に基づく最大距離アルゴリズムを用いることで, 人が見て違和感のない減色画像を可能であることを確認し た。さらに，得られたクラスタリングの結果を Canny edge detector の䦭值決定に用いることにより，従来法において 課題であった，ピクセルアート化に扔ける複数の適したパ ラメータを求めることが可能であることを実験的に示した，

\section{〔文献〕}

1) Johannes, K. and Dani, L.: "Depixelizing pixel art", $A C M$ Transactions on Graphics (Proceedings of SIGGRAPH 2011), 30, 4, pp. 99:1 - 99:8 (2011)

2）鈴木和明, 齋藤 豪, 張 英夏, 近藤邦雄, 中嶋正之： “単一オブジェク ト写真からドット絵風のキャラク夕画像を生成する手法の提案”，信学 論, J91-D, 12, pp. 2961-2972 (2008)

3) Vidya, S., Conrad, A. B., Amy, A. G., et al.: "Semanticon: Visual metaphors as file icons", Comput. Graph. Forum, 24, 3, pp. 647-656 (2005)

4）松島立弥，三上浩司：“シームカービング手法を用いた人物ドット絵制 作の効率化手法”, 第 8 回情報科学技術フォーラム (FIT 2009), pp. 293-294, (2009) 

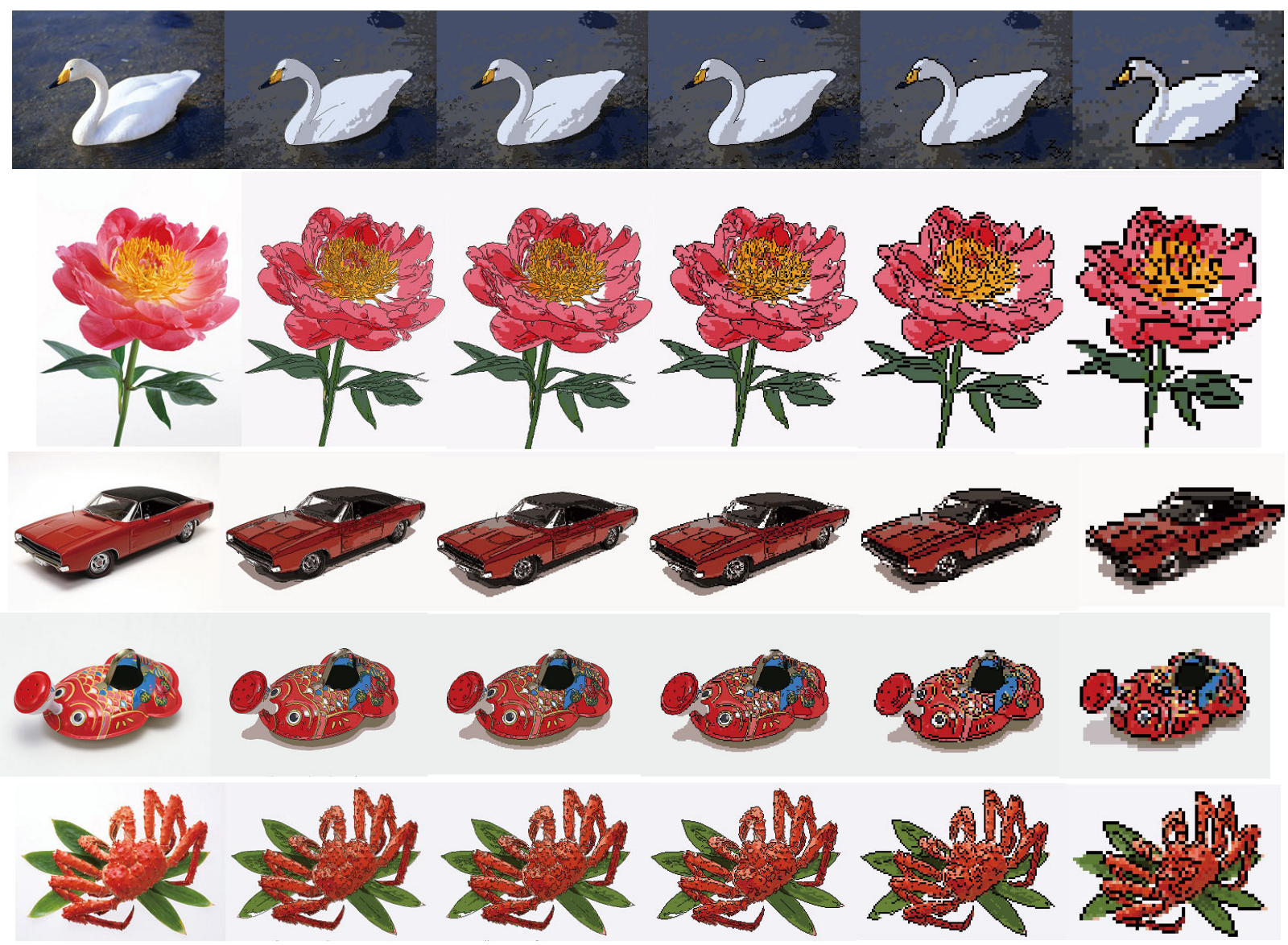

図 5 原画像と生成されたピクセルアートの例 (左から、原画像、縮小率 $100 \%, 70 \%, 40 \%, 20 \%, 10 \%$ )

The sample of created pixel art (original, 100\%,70\%,40\%,20\%,10\%).

5) Ruihua M. and Gurminder, S.: "Large-scale infographic image downsizing", Proc. of ICIP 2004, pp. 1661-1664, (2004)

6) Suguru, T.: “ドット絵職人一すべてのパソコンに入っている「ペイン 卜」ツールでつくる”，エムディエヌコーポレーション, (2007)

7）高野隼人：“ドット絵プロフェッショナルテクニックードット打ちから アニメーションまで”, 秀和システム, (2005)

8）日本色彩学会：東京大学出版会, 第 2 版, 新編色彩科学ハンドブック, (1998)

9) Pietro, P. and Jitendra, M.: "Scale-space and edge detection using anisotropic diffusion", IEEE Transactions on Pattern Analysis and Machine Intelligence, 12, 7, pp. 629-639 (1990)

10）田村秀行：“細線化についての諸考察”，信学技告, pp. 49-56 (1975)

11) David, A. and Sergei, V.: "k-means++: The advantages of careful seeding", Proc. of the eighteenth annual ACM-SIAM symposium on Discrete algorithms, pp. 1027-1035 (2007)

12) Dan, P. and Andrew, M.: "X-means: Extending kmeans with efficient estimation of the number of clusters", Proc. of the Seventeenth International Conference on Machine Learning, pp. 727-734 (2000)

13) Julius, T.T. and Rafael, G.: "Pattern Recognition Principles", Addison-Wesley, (1974)

14）長尾 真：“パターン情報処理”, 通信学会大学シリーズ，コロナ社, (1983)

15）井上光平, 原 健二, 浦浜喜一：“ロバストバイラテラルフィルタによる 混合雑音除去”，画像の認識・理解シンポジウム (MIRU2011) 講演論 文集, pp. 1012-1017 (2011)

16）松尾賢治，羽鳥好律：“異シードグラフカットによる拡大領域の重複 現象を利用した多領域画像分割”，信学論, J94-D, 8, pp. 1473-1485 (2011)

17）多々良友英，大橋剛介：“Canny エッジ検出による多重解像度エッジ画 像を用いたスケッチ画像検索”, 電気学論, 127(C), 11, pp. 1880-1887 (2007)

18）田村暁斗, 諸岡健一, 倉爪亮, ほか：“Adaboost 法による気道・食道画 像の識別”, 第 9 回システムインテグレーション部門講演会 (SI2008) 講演論文集, pp. 795-796 (2008)

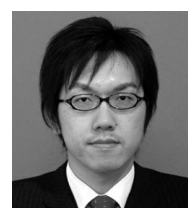

潼杂裕則 2004 年, 徳島大学大学院工学研究科 修士課程修了. 2005 年, 佐世保工業高等専門学校電子制 御工学科助手. 2007 年, 徳島大学大学院工学研究科博 士後期課程修了．博士 (工学) 。同年，佐世保高専助教， 2009 年，岡山県立大学情報工学部助教，現在に至る. 画 像処理, 感性情報処理などの研究に従事.

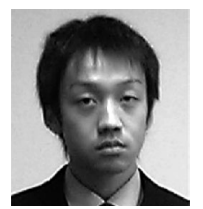

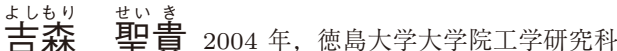
修士課程修了. 2007 年, 德島大学大学院工学研究科博士 後期課程修了。博士 (工学) . 2004 年, 日本文理大学工 学部講師, 現在に至る。主として, 画像処理に関する研 究に従事.

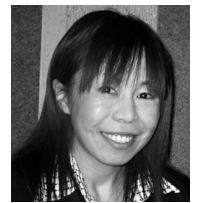

満倉 靖堛 1999 年, 徳島大学工学部知能情報工 学科助手. 2001 年, 徳島大学大学院工学研究科博士後 期課程短縮修了, 博士 (工学) . 2003 年, 岡山大学教育 学部技術科教育講師, 2006 年, 東京農工大学大学院助 教授, 2011 年, 慶應大学理工学部 准教授, 現在に至る。 画像処理, 生体信号解析, 信号処理の研究に従事. 